Original Article

\title{
Mutations in the bone morphogenetic protein 15 gene causing defective protein secretion in Cholistani infertile sheep
}

\author{
Mutações no gene da proteína morfogenética óssea 15 causadoras de defeitos na \\ secreção proteica em ovelhas inférteis Cholistani
}

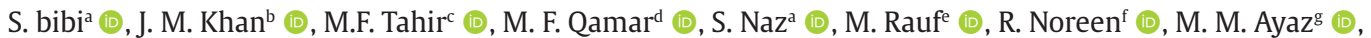

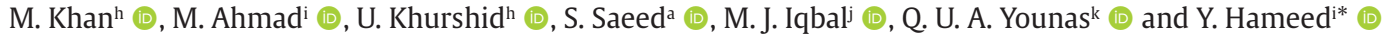 \\ aThe Government Sadiq College Women University Bahawalpur, Department of Zoology, Pakistan \\ ${ }^{\mathrm{b} C h o l i s t a n}$ University of Veterinary and Animal Sciences, Department of Parasitology, Bahawalpur, Pakistan \\ 'The University of Jhang, Department of Biochemistry, Jhang, Pakistan \\ ${ }^{d}$ College of Veterinary and Animal Sciences, Jhang, Pakistan \\ ${ }^{e}$ Cholistan University of Veterinary and Animal Sciences, Department of Pathology, Bahawalpur, Pakistan \\ ${ }^{\mathrm{f} G o v e r n m e n t ~ C o l l e g e ~ U n i v e r s i t y ~ F a i s a l a b a d, ~ D e p a r t m e n t ~ o f ~ B i o c h e m i s t r y, ~ F a i s a l a b a d, ~ P a k i s t a n ~}$ \\ ${ }^{g}$ Cholistan University of Veterinary and Animal Sciences, Bahawalpur, Pakistan

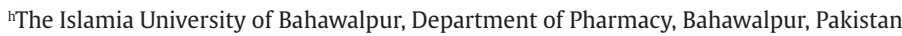 \\ iThe Islamia University of Bahawalpur, Department of Biochemistry and Biotechnology, Bahawalpur, Pakistan \\ jCOMASTS University Islamabad, Department of Biosciences, Islamabad, Pakistan \\ ${ }^{k}$ Cholistan University of Veterinary and Animal Sciences, Department of Zoology, Bahawalpur, Pakistan
}

\begin{abstract}
Naturally occurring mutations in morphogenetic protein 15 (BMP15) are associated with decreased ovulation rate (OR), litter size (LS), and sterility. It is of a great interest to elucidate BMP15 gene in Cholistani sheep breed to uplift socio-economic status and the knowledge of Cholistani sheep breeding in Southern Punjab, Pakistan. In our study, a total of 50 infertile Cholistani sheep aged between 2-6 years and having no blood relation were screened for BMP15 mutations. For this purpose, a high-quality DNA was extracted from the blood of sheep followed by primer designing, Polymerase Chain Reaction (PCR) amplification, DNA sequencing, and in silico analyses. Out of total 50 samples, 9 samples including case 1 (T3), case 2 (T8), case 3 (T17), case 4 (T22), case 5 (T25), case 6 (T33), case 7 (T40), case 8 (T44), and case 9 (T47) were found positive for a variety of already reported and novel BMP15 mutations. Further in silico analyses of the observed mutations have shown the functional impact of these mutations on different characteristics (molecular weight, theoretical PI, estimated half-life, instability index, sub-cellular localization, and 3D confirmation) of the encoded proteins, possibly altering the normal functionality. In a nutshell, findings of this study have confirmed the possible essential role of the BMP15 mutations in the infertility of the Cholistani sheep.
\end{abstract}

Keywords: BMP15, Cholistani sheep, PCR, mutations.

\begin{abstract}
Resumo
Mutações de ocorrência natural na proteína morfogenética 15 (BMP15) estão associadas à diminuição da taxa de ovulação (TO), tamanho da ninhada (TN) e esterilidade. Estudar a BMP15 na raça Cholistani para elevar o status socioeconômico e o conhecimento da criação de ovinos Cholistani no sul de Punjab, Paquistão. Em nosso estudo, 50 ovelhas Cholistani inférteis sem parentesco sanguíneo foram rastreadas para mutações BMP15. Para tanto, um DNA de alta qualidade foi extraído do sangue dessas ovelhas, seguido de concepção do primer, amplificação da reação em cadeia da polimerase (PCR), sequenciamento de DNA e análises in silico. Do total de 50 amostras, 9 , incluindo caso 1 (T3), caso 2 (T8), caso 3 (T17), caso 4 (T22), caso 5 (T25), caso 6 (T33), caso 7 (T40), caso 8 (T44) e caso 9 (T47), foram consideradas positivas para uma variedade de mutações BMP15 novas e já relatadas. Mais análises in silico das mutações observadas mostraram o impacto funcional dessas mutações em diferentes características (peso molecular, PI teórico, meia-vida estimada, índice de instabilidade, localização subcelular e confirmação 3D) das proteínas codificadas, possivelmente alterando a funcionalidade normal. Nossos achados confirmaram o possível papel essencial das mutações BMP15 na infertilidade de ovelhas Cholistani.
\end{abstract}

Palavras-chave: BMP15, ovelha Cholistani, PCR, mutações.

*e-mail: yasirhameed2011@gmail.com

Received: October 2, 2021 - Accepted: November 12, 2021 


\section{Introduction}

Cholistani sheep also known as Buchi sheep commonly found in the surrounding areas of district Bahawalpur, Multan and Rahim Yar Khan, Pakistan. These sheep have a thin tail and its body is covered with white coat and brown to black head and ears. They mainly raised in Pakistan for meat and wool production (Akhtar et al., 2012, 2014).

In past two decades, tremendous efforts have been made throughout the world to figure out major genes involved in the fertility of sheep. Three fecundity genes (Fec) namely; BMP15 (Bone Morphogenetic Protein 15) called as FecX, GDF9 (growth and differentiation factor 9) known as FecG and BMPR-IB (bone morphogenetic protein receptor type IB) also known as $F e c B$ are found to play an essential role in the folliculogenesis of sheep (Chu et al., 2005; Castro et al., 2016; Hanrahan et al., 2004; Niu et al., 2021). Interestingly, all these fecundity genes belong to the same TGF $\beta$ superfamily, transforming growth factor beta superfamily (Fabre et al., 2006).

In sheep, BMP15 gene is located on the X-chromosome and it has two exons (E1 and E2). This gene encodes for 393 amino-acid long pre-protein and a mature BMP15 protein containing 125 amino acids (Niu et al., 2021). The protein encoded by BMP15 gene only express in the oocytes of developing follicles, thus plays a key role in the fertility of mammals (Bodensteiner et al., 1999; Galloway et al., 2000). At present, a wide variety of BMP15 mutations have been identified in different breeds of sheep. Ewes (female sheep) carrying heterozygous BMP15 mutations are completely infertile due to lack of primary follicles in ovary while higher ovulation rate has been reported in homozygous mutants (Davis et al., 2001; Davis et al., 1995; Galloway et al., 2000; Hanrahan et al., 2004).

Many studies worldwide and in Pakistan have already reported the BMP15 mutations in different breeds of sheep (Bodin et al., 2007; Chu et al., 2005; Galloway et al., 2000; Hanrahan et al., 2004; Jalbani et al., 2017; Martinez-Royo et al., 2008; Monteagudo et al., 2009; Niu et al., 2021), but none of the study has reported the BMP15 mutations in infertile Cholistani sheep which are the major source of meat and wool in Southern Punjab, Pakistan. Keeping in view the role of BMP15 in sheep fertility, it is worth to investigate the mutational spectrum of BMP15 in infertile Cholistani sheep. The detection of BMP15 mutations is important to achieve the high-performance animals such as sheep and goat, etc. Therefore, it is of a great interest to study fecundity gene BMP15 in Cholistani breed to uplift socio-economic status and the knowledge of Cholistani sheep breeding in Southern Punjab, Pakistan.

In our study, we documented the role of BMP15 mutations in infertile Cholistani sheep using wet lab experiments as well as Bioinformatics analysis. Finally, this study has provided the BMP15 molecular characteristics knowledge in Cholistani sheep that would be helpful in improving the breeding standards among Cholistani sheep.

\section{Methodology}

Methodology of the current study includes two step approach including wet-lab and dry-lab experiments.

\subsection{Wet-lab experiments}

\subsubsection{Sample collection}

This study was initiated after the approval from Research and Ethics committee, The Government Sadiq College Women University, Bahawalpur. Blood samples of fifty infertile Cholistani sheep aged between 2-5 years and having no blood relation were collected from different Livestock farms of District Bahawalpur, Pakistan. No animal was harmed during the sample collection and blood samples were stored at $-30^{\circ} \mathrm{C}$ prior to DNA extraction.

\subsubsection{DNA extraction}

In total $500 \mu \mathrm{l}$ blood from each collected sample was processed for DNA extraction using organic method (Phenol-Chloroform extraction method) with slight modifications (Chacon-Cortes and Griffiths, 2014). Quantity and quality of each extracted DNA was analyzed through NanoDrop method and Agarose gel electrophoresis (GarcíaAlegría et al., 2020; Lee et al., 2012).

\subsubsection{Primer designing}

To amplify the coding exon 2 of BMP15 gene, two specific primer pairs were designed using Primer 3 tool available at https://bioinfo.ut.ee/primer3-0.4.0/ (Table. 1).

\subsubsection{PCR amplification and agarose gel electrophoresis}

PCR was performed in $50 \mu$ reaction mixture containing $5 \mu \mathrm{l}$ of $10 \mathrm{X}$ PCR Buffer, $5 \mu \mathrm{l}$ of $25 \mathrm{mM} \mathrm{MgCl}, 1 \mu \mathrm{ldNTP}$, $2 \mu \mathrm{l}$ of each primer (forward and reverse), $100 \mathrm{ng}$ genomic DNA, $0.25 \mu$ l Taq DNA polymerase and $29.75 \mu$ injection water. Conditions for the PCR amplification using Bio Rad Thermocycler are as follows; denaturation at $94^{\circ} \mathrm{C}$ for 5 minutes, annealing for 30 seconds at $57^{\circ} \mathrm{C}$, extension at $72^{\circ} \mathrm{C}$ for 30 seconds and final extension for 10 minutes at $72^{\circ} \mathrm{C}$. Finally, PCR amplicons were analyzed on $2 \%$ Agarose gel electrophoresis.

\subsubsection{Sequencing analysis of $P C R$ products}

PCR amplified products were sent to Macrogen, Seoul, Korea for Bi-directional Sanger sequencing analysis.

\subsection{Dry-lab experiments}

Following Bioinformatics tools and databases were used in the present study for comparative and mutational analysis of the obtained BMP15 amplicon sequences.

1) E N S E M B L (available at: https://asia.ensembl.org/ index. html), to obtain gene-related information.

2) BLAST (available at: https://blast.ncbi.nlm.nih.gov/ Blast.cgi), to find out the similarity of sequence across all genomes.

3) EBI alignment tool (available at: https://www.ebi. ac.uk/Tools/psa/), to align retrieved sequences against reference sequence. 
4) EXPASY translation tool (available at: https://web. expasy. org/translate), to translate cDNA sequence into their respective proteins.

5) PHYRE2 tool (available at: http://www.sbg.bio.ic.ac. uk/ phyre2/ html/page.cgi?id = index), to construct 3D structures of normal and mutant proteins.

6) ProtComp 9.0 tool (available at: http://www.softberry. com/berry.phtml?topic $=$ protcomp), to find out the subcellular localization of the mutant proteins.

7) ProtParam tool (available at: https://web.expasy. org/protparam/), to document physicochemical characteristics of the mutant proteins.

\section{Results}

In the present study, a total of 50 Cholistani sheep having no blood relation were screened for the BMP15 mutations. A high-quality DNA was extracted and PCR amplification was done using BMP15 gene specific primers (Table 1 ). The amplification positivity ratios of both primer pairs were $100 \%$ and all the amplified PCR amplicons were subjected to $2 \%$ agarose gel electrophoresis for quality check. In total 170 PCR amplicons showing high quality signals on the gel were further subjected to DNA sequence analysis. Out of 50, in total 9 sheep samples (T3, T8, T17, T22, T25, T33, T40, T44 and T47) were found positive for different kinds of DNA mutations in BMP15 gene. For convenience, all the 9 samples found positive for BMP15 mutations were categorized as case 1 (T3), case 2 (T8), case 3 (T17), case 4 (T22), case 5 (T25), case 6 (T33), case 7 (T40), case 8 (T44), and case 9 (T47).

\subsection{Detail of the observed BMP15 mutations and their} functional impact prediction in total 09 cases of Cholistani sheep

In case 1 , a total of 04 mutations including one non-sense (Q239Ter) and three missense mutations (P211R, V299D and $\mathrm{C} 321 \mathrm{Y}$ ) were documented (Table 2 and Figure 1). The observed three missense mutations were found to cause the abnormality in overall 3D configuration of the encoded protein while one non-sense mutation resulted in the formation of truncated BMP15 protein of 239 amino acids (Figure 2). Collectively, all these observed

Table 1. Characteristics of the designed primer pairs specific for exon 2 region of BMP15 gene.

\begin{tabular}{cccccc}
\hline Sr. No & Primer ID & Primer Sequence & Length & Product size & Target region \\
\hline 1 & BMP15F2 & 5'GAAGCTAACGCTTTGCTCTTG 3' & 21 & 472 bps & Exon 2 \\
& BMP15R2 & 5'TCAGGCCTTTAGGGAGAGGT 3' & 20 & & Exon 2 \\
\hline & BMP15F3 & 5'GCAGCCAAGAGGTAGTGAGG3' & 20 & 580bps & \\
& BMP15R3 & 5'CCTGAGCTAGCTGCACCTTT3' & 20 & & \\
\hline
\end{tabular}

Table 2. Mutations of exon2 in BMP15 gene of infertile Cholistani breed.

\begin{tabular}{|c|c|c|c|c|c|}
\hline Breed & Sample ID & Coding DNA position & Bp exchange & Amino Acid change & Mutation Type \\
\hline \multirow{21}{*}{$\begin{array}{c}\text { Cholistani } \\
\text { (Buchi) }\end{array}$} & Case 1 & c. $632 \mathrm{C}>\mathrm{G}$ & CCA-CGA & P211R & Missense \\
\hline & & c. $718 \mathrm{C}>\mathrm{T}$ & CAG-TAG & Q239Ter & Nonsense \\
\hline & & c.896T $>$ A & GTC-GAC & V299D & Missense \\
\hline & & c.962G $>A$ & TGT-TAT & C321Y & Missense \\
\hline & Case 2 & c. $403 \mathrm{G}>\mathrm{A}$ & GTT-ATT & V135I & Missense \\
\hline & Case 3 & c. $871 \mathrm{C}>\mathrm{T}$ & CAG-TAG & Q291Ter & Nonsense \\
\hline & Case 4 & c.755T $>C$ & CTG-CCG & L252P & Missense \\
\hline & & c. $809 \mathrm{C}>\mathrm{A}$ & GCA-GAA & A270E & Missense \\
\hline & & c. $842 \mathrm{C}>\mathrm{T}$ & TCC-TTC & S281F & Missense \\
\hline & & c. $1041 G>C$ & GAG-GAC & E347D & Missense \\
\hline & Case 5 & c. $809 \mathrm{C}>\mathrm{A}$ & GCA-GAA & A270E & Missense \\
\hline & & c.896T $>$ A & GTC-GAC & V299D & Missense \\
\hline & & c. $1100 \mathrm{G}>\mathrm{T}$ & AGC-ATC & S367I & Missense \\
\hline & Case 6 & c. $632 C>G$ & CCA-CGA & P211R & Missense \\
\hline & & c. $718 \mathrm{C}>\mathrm{T}$ & CAG-TAG & Q239Ter & Nonsense \\
\hline & Case 7 & c.755T $>C$ & CTG-CCG & L252P & Missense \\
\hline & & c.962G>A & TGT-TAT & C321Y & Missense \\
\hline & & c. $1100 \mathrm{G}>\mathrm{T}$ & AGC-ATC & S367I & Missense \\
\hline & Case 8 & c. $718 \mathrm{C}>\mathrm{T}$ & CAG-TAG & Q239Ter & Nonsense \\
\hline & Case 9 & c. $755 \mathrm{~T}>\mathrm{C}$ & CTG-CCG & L252P & Missense \\
\hline & & c. $1053 \mathrm{G}>\mathrm{A}$ & CAG-CAA & Q351Q & Silent \\
\hline
\end{tabular}




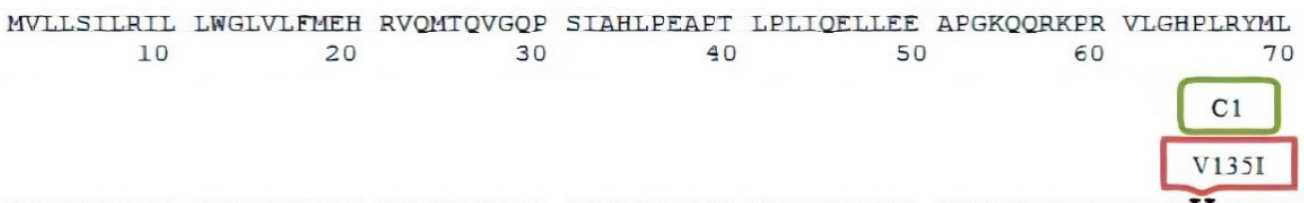

ELYQRSADAS GHPRENRTIG ATMVRLVRPL ASVARPLRGS WHIOTLDFPL RPNRVAYQLV RATVVYRHOL
80
90
100
110
120
130
140

HLTHSHLSCH VEPWVQKSPT NHFPSSGRGS SKPSLLPKTW TEMDTMEHVG QKLWNHKGRR VLRLRFVCQQ

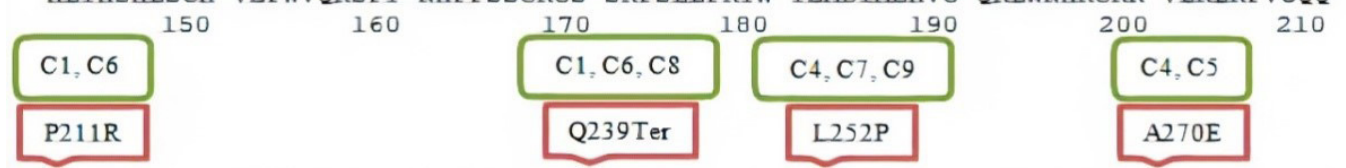

PRGSEVLEFW WHGISSLDTV FLLLYFNDTQ SVQKTKPLPK GLKEFIEKDP SLLLRRARQA GSIASEVPGP

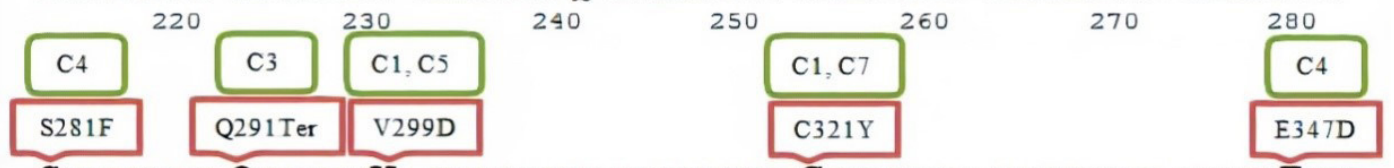

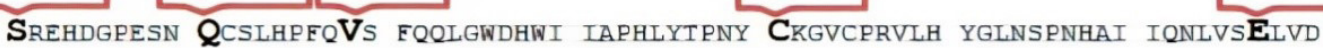

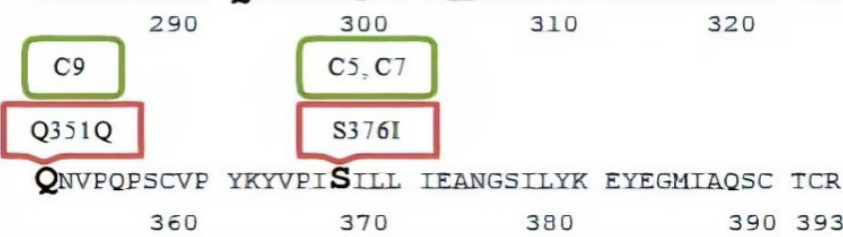

Figure 1. Representation of all the documented mutations in BMP15 protein of Cholistani sheep. Red box contains mutation detail and green box presents case number (C) which contains that particular mutation.

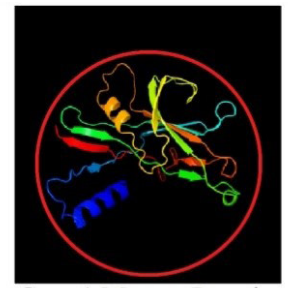

Case 1 Mutant Protein

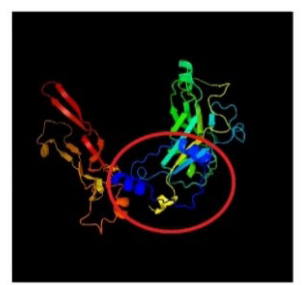

Case 9 Mutant Protein

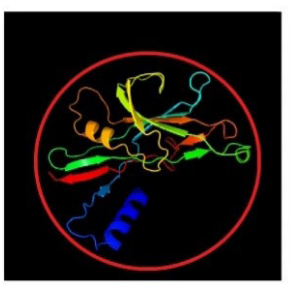

Case 8 Mutant Protein

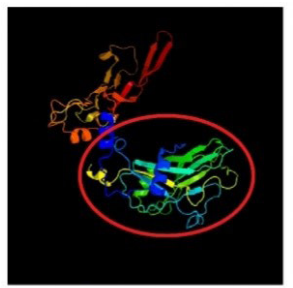

Case 2 Mutant Protein

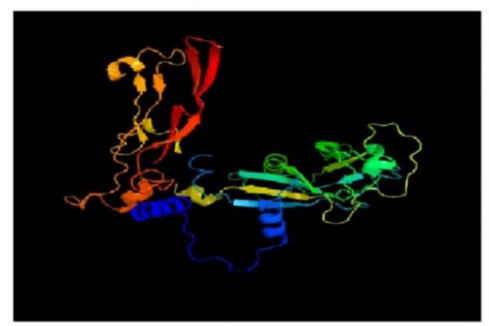

Normal BMP15 Protein

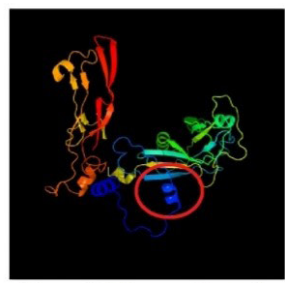

Case 7 Mutant Protein

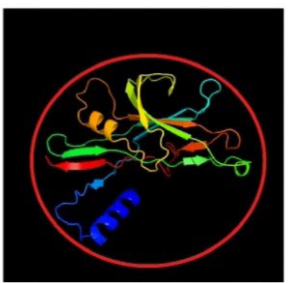

Case 6 Mutant Protein

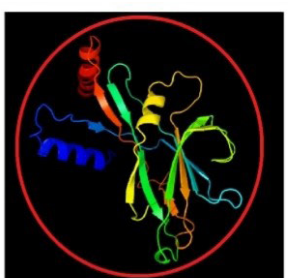

Case 3 Mutant Protein

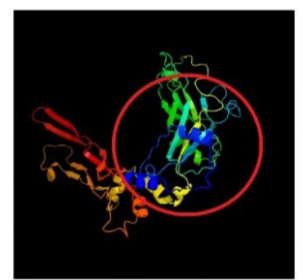

Case 4 Mutant Protein

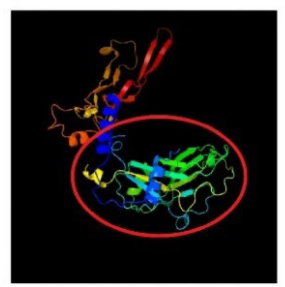

Case 5 Mutant Protein

Figure 2. Phyre2 based constructed 3D structures of normal and mutant BMP15 proteins in different cases of Cholistani sheep. Red circle indicates the observed variations in different domains between normal and encoded mutant BMP15 proteins. 
mutations were also found to be associated with the change in subcellular-localization of the encoded mutant protein from membrane bound extracellular (Secreted) to extracellular (Secreted) (Table 3). Moreover, in view to our results, we also found a change in molecular weight, theoretical PI, and stability index of the encoded mutant protein relative to the normal BMP15 protein (Table 4).

In case 2 and case 3, only one missense (V135I) and non-sense mutation (Q291Ter) were noticed, respectively (Table 2 and Figure 1). The observed missense mutation in case 2 was found to cause the abnormality in overall $3 \mathrm{D}$ structure of the encoded protein while the non-sense mutation in case 3 caused the formation of truncated protein of 291 amino acids (Figure 2). Moreover, both of these mutations were also found to be linked with the change in molecular weight, theoretical PI, and stability index of the encoded BMP15 proteins in both cases (case 2 and case 3 ) but not with the subcellular-localization (Table 4).

A total of 4 (L252P, A270E, S281F, E347D) and 3 (A270E, V299D, S367I) missense mutations were observed in case 4 and case 5 , respectively (Table 2 and Figure 1 ). All the mutations in both cases were found to cause the abnormality in overall 3D configuration of the encoded BMP15 proteins (Figure 2). Moreover, these mutations were also associated with a change in molecular weight, theoretical PI, and stability index of the encoded mutant proteins but not with the subcellular-localization (Table 4).

In case 6, one missense (P211R) and non-sense mutation (Q239Ter) were documented (Table 2 and Figure 1).

Table 3. Localization of the normal and mutant BMP15 protein in different cases of Cholistani sheep.

\begin{tabular}{|c|c|c|c|c|c|c|}
\hline \multirow{2}{*}{ Protein type } & \multirow{2}{*}{ Localization } & \multicolumn{5}{|c|}{ Scores in different databases } \\
\hline & & LocDB & Pot LocDB & Naural Nets & Pentamers & Integral \\
\hline Normal BMP15 & $\begin{array}{l}\text { Membrane bound } \\
\text { Extracellular (Secreted) }\end{array}$ & 10.0 & 3.0 & 0.76 & 3.07 & 9.99 \\
\hline Case 1 & Extracellular (Secreted) & 10.0 & 3.0 & 2.31 & 3.09 & 10.0 \\
\hline Case 2 & $\begin{array}{l}\text { Membrane bound } \\
\text { Extracellular (Secreted) }\end{array}$ & 10.0 & 3.0 & 0.83 & 3.07 & 9.99 \\
\hline Case 3 & $\begin{array}{l}\text { Membrane bound } \\
\text { Extracellular (Secreted) }\end{array}$ & 10.0 & 3.0 & 2.0 & 3.12 & 10.0 \\
\hline Case 4 & $\begin{array}{l}\text { Membrane bound } \\
\text { Extracellular (Secreted) }\end{array}$ & 10.0 & 3.0 & 0.16 & 3.08 & 9.96 \\
\hline Case 5 & $\begin{array}{l}\text { Membrane bound } \\
\text { Extracellular (Secreted) }\end{array}$ & 10.0 & 3.0 & 0.32 & 3.07 & 9.97 \\
\hline Case 6 & Extracellular (Secreted) & 10.0 & 3.0 & 2.31 & 3.09 & 10.0 \\
\hline Case 7 & $\begin{array}{l}\text { Membrane bound } \\
\text { Extracellular (Secreted) }\end{array}$ & 10.0 & 3.0 & 0.23 & 3.09 & 9.97 \\
\hline Case 8 & Extracellular (Secreted) & 10.0 & 3.0 & 2.33 & 3.07 & 10.0 \\
\hline Case 9 & $\begin{array}{l}\text { Membrane bound } \\
\text { Extracellular (Secreted) }\end{array}$ & 10.0 & 3.0 & 0.69 & 3.07 & 10.0 \\
\hline
\end{tabular}

Table 4. Physiochemical characteristics of the normal and mutant BMP15 protein in different cases of Cholistani sheep.

\begin{tabular}{cccccc}
\hline Protein Type & $\begin{array}{c}\text { No. of amino- } \\
\text { acids }\end{array}$ & Molecular weight & Theoretical PI & $\begin{array}{c}\text { Estimated half } \\
\text { life }\end{array}$ & Instability Index \\
\hline Normal BMP15 & 393 & 44899.95 & 9.46 & 30 hours & 48.05 \\
Case 1 & 239 & 27725.29 & 10.54 & 30 hours & 45.13 \\
Case 2 & 393 & 44913.98 & 9.46 & 30 hours & 48.25 \\
Case 3 & 290 & 33216.45 & 10.23 & 30 hours & 46.75 \\
Case 4 & 393 & 44988.02 & 9.39 & 30 hours & 47.78 \\
Case 5 & 393 & 45000.03 & 9.31 & 30 hours & 49.72 \\
Case 6 & 239 & 27725.29 & 10.54 & 30 hours & 45.13 \\
Case 7 & 393 & 44970.03 & 9.49 & 30 hours & 48.58 \\
Case 8 & 293 & 27666.22 & 10.39 & 30 hours & 43.23 \\
Case 9 & 393 & 44883.91 & 9.46 & 30 hours & 48.27 \\
\hline
\end{tabular}


Collectively, both of these mutations caused abnormality in overall 3D structure of encoded protein while the nonsense mutation caused the formation of truncated BMP15 protein of 239 amino acids (Figure 2). Furthermore, both these mutations were revealed to be linked with the change in subcellular-localization of the encoded mutant protein from membrane bound extracellular (Secreted) to extracellular (Secreted) (Table 3). Moreover, these mutations were associated with the change in molecular weight, theoretical PI, and stability index of the encoded BMP15 proteins (Table 4).

Only one non-sense mutation (Q239Ter) was noticed in case 8 (Table 2 and Figure 1). This mutation caused the formation of truncated protein of 291 amino-acids (Figure 2) and found to be associated with the change in subcellular-localization of the encoded mutant BMP15 protein from membrane bound extracellular (Secreted) to extracellular (Secreted) (Table 3). Moreover, the change in molecular weight, theoretical PI, and stability index of the encoded mutant BMP15 protein were also linked with the observed mutation (Table 4).

In case 9, one missense (L252P) and silent mutation (Q351Q) was documented (Table 2 and Figure 1). The observed missense mutation caused abnormality in the overall 3D configuration of mutant protein while the silent mutation has no effect on protein structure (Figure 2). Moreover, these mutations do not have any impact on the localization of mutant BMP15 protein (Table 4).

\section{Discussion}

Bone Morphogenetic Protein 15 (BMP15) gene plays an important role in the fecundity of sheep (Ovis aries) and this gene can be used as a potential target to increase the fecundity in mammals (Juengel et al., 2002; Niu et al., 2021). The current study aimed to explore the mutational spectrum of BMP15 in Cholistani sheep which will be very useful for breeding purpose.

Previously, a variety of BMP15 mutations were identified in different breeds of sheep worldwide. For example, Hanrahan et al. have reported Q239Ter and S367I BMP15 mutations in Belclare and Cambridge sheep breeds (Hanrahan et al., 2004). Truncated BMP15 protein formed due to Q239Ter mutation caused infertility as MBP15 protein is an essential factor for follicular development in sheep while S367I (c.1100G>T) mutation affects the receptor binding affinity of BMP15 because a polar amino-acid serine is replaced by non-polar amino-acid isoleucine (Galloway et al., 2000; Hanrahan et al., 2004). Niu et al. documented p.L252P BMP15 mutation in Cele black sheep which affect the fertility of this sheep. Moreover, it might also influence the litter size of sheep (Niu et al., 2021). Galloway et al. have reported Q291Ter and V299D BMP15 mutations in New Zealand Romney. Nonsense mutation Q291Ter will lead to the production of truncated BMP15 protein while c.896T >A (V299D) mutation disrupts the dimmer formation ability of BMP15 protein as hydrophobic valine is replaced by negatively charged aspartic acid. This replacement effect the electrostatic surface potential of non-charged area involved in dimer formation of BMP15
(Galloway et al., 2000). Bodin et al. C321Y in French Lacaune

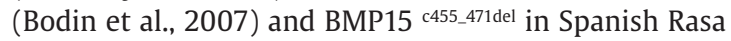
Aragonesa (Martinez-Royo et al., 2008; Monteagudo et al., 2009).

We collected 50 blood samples from infertile Cholistani sheep and processed it for DNA extraction and the amplification of BMP15 using conventional PCR with gene specific primers. Further, sequencing analysis showed a variety of mutations in total 09 cases of Cholistani sheep. The details of the observed mutations are as follows:

In case 1, we observed one non-sense (Q239Ter) and three missense mutations (P211R, V299D and C321Y) in BMP15 gene of Cholistani sheep. Phyre 2 web tool showed c.718C > T (Q239Ter) mutation will result in premature truncated protein (Figure 2). Earlier studies report that premature truncated protein due to Q239Ter mutation caused infertility in sheep as MBP15 gene is an essential factor for follicular development (Galloway et al., 2000; Hanrahan et al., 2004). Best to our knowledge we are the first one to report c.632C $>\mathrm{G}$ (P211R) mutation in BMP15 gene of Cholistani sheep. BMP15 is active in its dimer form while c.896T $>$ A (V299D) mutation disrupts the dimmer formation as hydrophobic valine is replaced by negatively charged aspartic acid. This replacement effect the electrostatic surface potential of non-charged area involved in dimer formation of BMP15 (Galloway et al., 2000). Furthermore, c.962G>A (C321Y) mutation interferes in the maturation of BMP15 leading to immature secretion of the BMP15 protein (Bodin et al., 2007).

A single missense c.403G $>A$ (V135I) mutation of BMP15 was documented in case 2 . This mutation has not been reported earlier in any published literature.

In case 3, only one non-sense c.871C>T (Q291Ter) mutation was documented in BMP15 gene. Previously reported study support the findings of Phyre ${ }^{2}$ web tool that c.871C>T (Q291Ter) mutation in BMP15 will lead to the production of premature truncated protein as shown in Figure 2 (Galloway et al., 2000).

Four missense mutations (L252P, A270E, S281F and E347D) were noticed in BMP15 gene of Cholistani sheep in case 4 . A previously reported study showed that c.755T $>C$ (L252P) mutation in BMP15 gene affect the fertility of Cele black sheep and it might also influence the litter size of the sheep (Niu et al., 2021). Beast to our knowledge c.809C $>$ A, c.842C $>$ T and c.1041G $>$ C (A270E, S281F and E347D) mutations have not been reported earlier in any of the published literature.

In case 5, we observed three missense mutations (A270E, V299D and S367I) in BMP15 gene of Cholistani sheep. A mutation c.809C $>\mathrm{A}$ (A270E) has not been reported earlier in any of the published literature. However, a previously reported study showed that c.896T $>$ A (V299D) mutation affect the dimer formation capability of BMP15 gene (Galloway et al., 2000). Furthermore, a study has already reported the c.1100G>T (S367I) mutation in BMP15 gene where a polar amino-acid serine is replaced by non-polar amino-acid isoleucine. This mutation probably affects the receptor binding affinity of BMP15 (Hanrahan et al., 2004).

In case 6 , one missense $c .632 \mathrm{C}>\mathrm{G}(\mathrm{P} 211 \mathrm{R})$ as well as one non-sense mutation c.718C $>\mathrm{T}(\mathrm{Q} 239 \mathrm{Ter})$ was documented in BMP15 gene of Cholistani sheep. Best to our knowledge 
we are the first one to report c.632C $>\mathrm{G}$ (P211R) mutation in BMP15 gene of Cholistani sheep. However, previously reported studies support the findings of Phyre $^{2}$ web tool that c.718C > T (Q239Ter) mutation in BMP15 will lead to the production of premature truncated protein (Figure 2 ) resulting in the infertility of sheep (Galloway et al., 2000; Hanrahan et al., 2004)

In case 7, a total of three missense mutations (L252P, C321Y and S367I) were noticed in in BMP15 gene of Cholistani sheep. A mutation c.755T >C (L252P) in BMP15 gene is known to affect the fertility of Cele black sheep and it might also influence the litter size of the sheep (Niu et al., 2021). However, c.962G>A (C321Y) mutation interferes in the maturation of BMP15 leading to immature secretion of the BMP15 protein (Bodin et al., 2007). Furthermore, a previously reported study showed c.1100G $>$ T (S367I) mutation disrupt the biological function of BMP15 by affecting its receptor binding affinity (Hanrahan et al., 2004).

A single non-sense mutation c.718C $>\mathrm{T}$ (Q239Ter) of BMP15 was documented in case 8. Previously reported studies support the findings of Phyre 2 web tool that c.718C $>$ T (Q239Ter) mutation in BMP15 will lead to the production of premature truncated protein (Figure 2) resulting in the infertility of sheep (Galloway et al., 2000; Hanrahan et al., 2004).

In case 9, one missense (L252P) as well as one silent mutation (Q351Q) was observed in the BMP15 gene of Cholistani sheep. A previously reported study showed that c.755T $>C$ (L252P) mutation in BMP15 gene affect the fertility of Cele black sheep and it might also influence the litter size of the sheep (Niu et al., 2021). However, none of the study have reported the $c .1053 \mathrm{G}>\mathrm{A}(\mathrm{Q} 351 \mathrm{Q})$ mutation in BMP15 gene of the Cholistani sheep.

\section{Conclusion}

Current study has reported the mutational spectrum of BMP15 in Cholistani sheep, which will be helpful to understand the molecular characteristics of BMP15 in Cholistani sheep and will also lead to improve breeding standard among sheep.

\section{Acknowledgements}

None.

\section{References}

AKHTAR, M., JAVED, K. and ABDULLAH, M., 2014. Single trait analysis for preweaning growth traits of Buchi sheep in Pakistan. The Journal of Animal \& Plant Sciences, vol. 24, no. 3, pp. 693-699.

AKHTAR, M., JAVED, K., ABDULLAH, M., AHMAD, N. and ELZO, M., 2012. Environmental factors affecting preweaning growth traits of Buchi sheep in Pakistan. The Journal of Animal E Plant Sciences, vol. 22, no. 3, pp. 529-536.

BODENSTEINER, K.J., CLAY, C., MOELLER, C. and SAWYER, H., 1999. Molecular cloning of the ovine growth/differentiation factor-9 gene and expression of growth/differentiation factor-9 in ovine and bovine ovaries. Biology of Reproduction, vol. 60, no. 2, pp. 381-386. http://dx.doi.org/10.1095/biolreprod60.2.381. PMid:9916005.

BODIN, L., DI PASQUALE, E., FABRE, S., BONTOUX, M., MONGET, P., PERSANI, L. and MULSANT, P., 2007. A novel mutation in the bone morphogenetic protein 15 gene causing defective protein secretion is associated with both increased ovulation rate and sterility in Lacaune sheep. Endocrinology, vol. 148, no. 1, pp. 393-400. http://dx.doi.org/10.1210/en.2006-0764. PMid: 17038554.

CASTRO, F.C., CRUZ, M.H.C. and LEAL, C.L.V., 2016. Role of growth differentiation factor 9 and bone morphogenetic protein 15 in ovarian function and their importance in mammalian female fertility: a review. Asian-Australasian Journal of Animal Sciences, vol. 29, no. 8, pp. 1065-1074. http://dx.doi.org/10.5713/ ajas.15.0797. PMid:26954112.

CHACON-CORTES, D. and GRIFFITHS, L.R., 2014. Methods for extracting genomic DNA from whole blood samples: current perspectives. Journal of Biorepository Science for Applied Medicine, vol. 2, pp. 1-9.

CHU, M.X., SANG, L.H., WANG, J.Y., FANG, L. and YE, S.C., 2005. Study on BMP15 and GDF9 as candidate genes for prolificacy of Small Tail Han sheep. Yi chuan xue bao, vol. 32, no. 1, pp. 38-45. [in Chinese]. PMid:15715436.

DAVIS, G., BRUCE, G. and DODDS, K., 2001. Ovulation rate and litter size of prolific Inverdale (FecXI) and Hanna (FecXH) sheep. Association for the Advancement of Animal Breeding and Genetics, vol. 14, pp. 175-178.

DAVIS, G., MCEWAN, J., FENNESSY, P. and DODDS, K., 1995. Discovery of the inverdale gene (FecX). Proceedings of the New Zealand Society of Animal Production, vol. 55, pp. 289-290.

FABRE, S., PIERRE, A., MULSANT, P., BODIN, L., DI PASQUALE, E., PERSANI, L., MONGET, P. and MONNIAUX, D., 2006. Regulation of ovulation rate in mammals: contribution of sheep genetic models. Reproductive Biology and Endocrinology, vol. 4, no. 1, pp. 20. http://dx.doi.org/10.1186/1477-7827-4-20. PMid:16611365.

GALLOWAY, S.M., MCNATTY, K.P., CAMBRIDGE, L.M., LAITINEN, M.P., JUENGEL, J.L., JOKIRANTA, T.S., MCLAREN, R.J., LUIRO, K., DODDS, K.G., MONTGOMERY, G.W., BEATTIE, A.E., DAVIS, G.H. and RITVOS, O., 2000. Mutations in an oocyte-derived growth factor gene (BMP15) cause increased ovulation rate and infertility in a dosage-sensitive manner. Nature Genetics, vol. 25, no. 3, pp. 279-283. http://dx.doi.org/10.1038/77033. PMid: 10888873.

GARCÍA-ALEGRÍA, A.M., ANDURO-CORONA, I., PÉREZ-MARTÍNEZ, C.J., CORELLA-MADUEÑO, M.A.G., RASCÓN-DURÁN, M.L. and ASTIAZARAN-GARCIA, H., 2020. Quantification of DNA through the NanoDrop Spectrophotometer: methodological validation using standard reference material and sprague dawley rat and human DNA. International Journal of Analytical Chemistry, vol. 2020, pp. 8896738. http://dx.doi.org/10.1155/2020/8896738. PMid:33312204.

HANRAHAN, J.P., GREGAN, S.M., MULSANT, P., MULLEN, M., DAVIS, G.H., POWELL, R. and GALLOWAY, S.M., 2004. Mutations in the genes for oocyte-derived growth factors GDF9 and BMP15 are associated with both increased ovulation rate and sterility in Cambridge and Belclare sheep (Ovis aries). Biology of Reproduction, vol. 70, no. 4, pp. 900-909. http://dx.doi. org/10.1095/biolreprod.103.023093. PMid:14627550.

JALBANI, M.A., KALERI, H.A., BALOCH, A.H., BANGULZAI, N., BUGTI, A.G., ASHRAF, F., KALERI, R.R., JAN, M., BUGTI, G.A. and KHOSA, A.N., 2017. Study of BMP15 gene polymorphisim in Lehri goat breed of Balochistan. Journal of Applied Environmental and Biological Sciences, vol. 7, pp. 84-89. 
JUENGEL, J.L., HUDSON, N.L., HEATH, D.A., SMITH, P., READER, K.L., LAWRENCE, S.B., O'CONNELL, A.R., LAITINEN, M.P., CRANFIELD, M., GROOME, N.P., RITVOS, O. and MCNATTY, K.P., 2002. Growth differentiation factor 9 and bone morphogenetic protein 15 are essential for ovarian follicular development in sheep. Biology of Reproduction, vol. 67, no. 6, pp. 1777-1789. http://dx.doi. org/10.1095/biolreprod.102.007146. PMid:12444053.

LEE, P.Y., COSTUMBRADO, J., HSU, C. and KIM, Y.H., 2012. Agarose gel electrophoresis for the separation of DNA fragments. Journal of Visualized Experiments, vol. 62, pp. e3923. http://dx.doi. org/10.3791/3923. PMid:22546956.

MARTINEZ-ROYO, A., JURADO, J., SMULDERS, J., MARTI, J., ALABART, J., ROCHE, A., FANTOVA, E., BODIN, L., MULSANT, P., SERRANO, M., FOLCH, J. and CALVO, J.H., 2008. A deletion in the bone morphogenetic protein 15 gene causes sterility and increased prolificacy in Rasa Aragonesa sheep. Animal Genetics, vol. 39, no. 3, pp. 294-297. http://dx.doi.org/10.1111/j.13652052.2008.01707.x. PMid:18355397.

MONTEAGUDO, L.V., PONZ, R., TEJEDOR, M.T., LAVIÑA, A. and SIERRA, I., 2009. A 17 bp deletion in the Bone Morphogenetic Protein 15 (BMP15) gene is associated to increased prolificacy in the Rasa Aragonesa sheep breed. Animal Reproduction Science, vol. 110, no. 1-2, pp. 139-146. http://dx.doi.org/10.1016/j. anireprosci.2008.01.005. PMid:18282670.

NIU, Z., QIN, J., JIANG, Y., DING, X., DING, Y., TANG, S. and SHI, H., 2021. The identification of mutation in BMP15 gene associated with litter size in Xinjiang cele black sheep. Animals, vol. 11, no. 3, pp. 668. http://dx.doi.org/10.3390/ani11030668. PMid:33802361. 
ERRATUM

\section{ERRATUM: Mutations in the Bone Morphogenetic Protein 15 Gene Causing Defective Protein Secretion in Cholistani Infertile sheep}

In the article "Mutations in the Bone Morphogenetic Protein 15 Gene Causing Defective Protein Secretion in Cholistani Infertile sheep”, DOI: https://doi.org/10.1590/1519-6984.256923, published in Braz. J. Biol. vol.84 São Carlos 2024 Epub February 2022, in the Title page of the article (authors affiliations):

Where it reads:

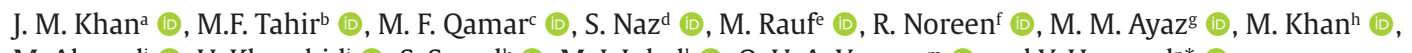

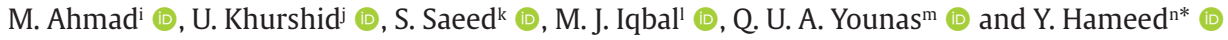

${ }^{a}$ Cholistan University of Veterinary and Animal Sciences, Department of Parasitology, Bahawalpur, Pakistan

${ }^{\mathrm{b}}$ The University of Jhang, Department of Biochemistry, Jhang, Pakistan

'College of Veterinary and Animal Sciences, Jhang, Pakistan

'The Government Sadiq College Women University Bahawalpur, Department of Zoology, Pakistan

eCholistan University of Veterinary and Animal Sciences, Department of Pathology, Bahawalpur, Pakistan

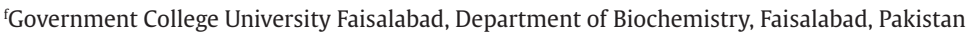

${ }^{8}$ Cholistan University of Veterinary and Animal Sciences, Bahawalpur, Pakistan

hThe Islamia University of Bahawalpur, Department of Pharmacy, Bahawalpur, Pakistan

The Islamia University of Bahawalpur, Department of Biochemistry and Biotechnology, Bahawalpur, Pakistan

iThe Islamia University of Bahawalpur, Department of Pharmacy, Bahawalpur, Pakistan

${ }^{k}$ The Government Sadiq College Women University, Department of Zoology, Bahawalpur, Pakistan

'COMASTS University Islamabad, Department of Biosciences, Islamabad, Pakistan

${ }^{\mathrm{m} C h o l i s t a n}$ University of Veterinary and Animal Sciences, Department of Zoology, Bahawalpur, Pakistan

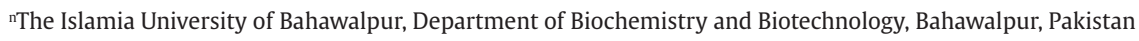

It should be read:

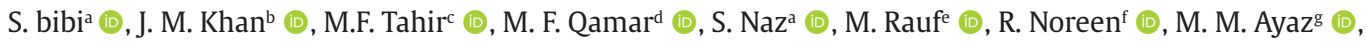

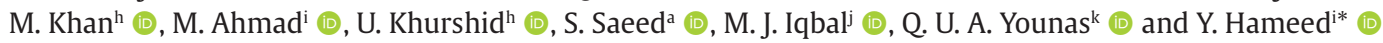
aThe Government Sadiq College Women University Bahawalpur, Department of Zoology, Pakistan ${ }^{\mathrm{b}}$ Cholistan University of Veterinary and Animal Sciences, Department of Parasitology, Bahawalpur, Pakistan 'The University of Jhang, Department of Biochemistry, Jhang, Pakistan

${ }^{\mathrm{d} C o l l e g e}$ of Veterinary and Animal Sciences, Jhang, Pakistan

eCholistan University of Veterinary and Animal Sciences, Department of Pathology, Bahawalpur, Pakistan

fGovernment College University Faisalabad, Department of Biochemistry, Faisalabad, Pakistan

${ }^{8}$ Cholistan University of Veterinary and Animal Sciences, Bahawalpur, Pakistan

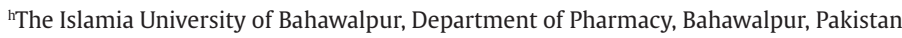

'The Islamia University of Bahawalpur, Department of Biochemistry and Biotechnology, Bahawalpur, Pakistan

jCOMASTS University Islamabad, Department of Biosciences, Islamabad, Pakistan

${ }^{k}$ Cholistan University of Veterinary and Animal Sciences, Department of Zoology, Bahawalpur, Pakistan 